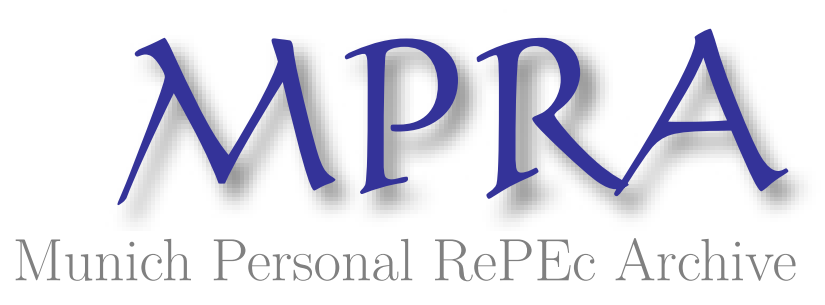

\title{
The Interest Rate Brake on Maturity Transformation
}

Howden, David and Gabriel, Amadeus

2015

Online at https://mpra.ub.uni-muenchen.de/79793/

MPRA Paper No. 79793, posted 19 Jun 2017 15:04 UTC 
This article can be cited as: David Howden \& Amadeus Gabriel. 2015. The Interest Rate Brake on Maturity Transformation. Journal of Economic Issues 49(4): 1100-1111.

To link to this article: http://dx.doi.org/10.1080/00213624.2015.1105046

The Interest Rate Brake on Maturity Transformation

David Howden and Amadeus Gabriel

[dhowden@slu.edu; gabriela@esc-larochelle.fr]

David Howden is Professor of Economics and chair of the Division of Business and Economics at Saint Louis University-Madrid Campus. Amadeus Gabriel is an Associate Professor in the Department of Finance and Economics at the Groupe Supérieure de Commerce de la Rochelle (France).

\begin{abstract}
Must banks match asset and liability maturities, as William Barnett and Walter E. Block $(2009,2011)$ as well as Ivan Jankovic (2011) surmise? While we agree with these authors that issuances of fiduciary media breed financial instability, we disagree that maturity transformation represents such a case. Maturity transformation otherwise known as borrowing short-term and lending long-term - guided by several base legal principles, does not result in the issuance of fiduciary media. Most notable among these principles is that any credit issued must be funded by borrowing of a positive duration, i.e., not via a demand deposit. We demonstrate that two factors instigate larger degrees of maturity transformation than would otherwise be the case, breeding potential instability: a continual increase in the credit supply and the provision of a lender of last resort. We also show that the interest rate is a natural stabilizing brake on the overissuance of longer-dated credit against short-term financing.
\end{abstract}

Keywords: bank assets, deposits, loans, maturity mismatch

JEL Classification Codes: G2, K22

Must banks abide by the "golden rule" of banking, as Ludwig von Mises $(1971,263)$ surmised? While this golden rule - that a bank's obligations must not fall due on a date prior to their corresponding claims - has existed since at least Otto Hübner $(1854,28)$, the idea contradicts what is widely seen as a the primary role of modern banking institutions (Freixas and Rochet 2008, 4). The practice exists today under various guises, including maturity transformation, maturity mismatching, and borrowing short-term and lending long-term.

Maturity transformation by the banking industry has been widely seen as a leading cause of the resultant instability in the wake of the 2008 financial crisis (Brunnermeier 2009). When regulatory measures failed to halt destabilizing investment activities, the collective maturity transformation of the banking industry left the monetary and fiscal authorities with little choice but to facilitate refinancing as the crisis progressed, lest the banking system succumb to a contagious series of insolvencies (Farhi and Tirole 2012). The on-demand nature of a bank's liabilities (e.g., demand deposits) exposes it to illiquidity if a sufficient amount of withdrawals 
exhausts its reserve assets. Alternatively, the par-value nature of the bank's liabilities implies that it can become insolvent (both cash flow and balance sheet) if its assets lose a sufficient amount of value on the market. While these common problems with maturity transformation are mitigated through deposit insurance, larger issues remain. On one hand, from a depositor's point-of-view, bouts of illiquidity brought about by maturity transformation disrupt banking services and potentially leave them unable to access their funds when the need arises. Since the government backstops the deposit insurance plan, bank instability often negatively affects its financing. (In addition to its deposit insurance fund, the FDIC holds a $\$ 500$-billion line of credit with the U.S. Treasury in case emergency funding is required.) On the other hand, runs on deposits increase regulatory scrutiny for all banks in the industry, even for those not directly affected by the turmoil. To the extent that bank employees can see their employment situation worsen in the event of a bank failure, they too have reason to be cautious of maturity transformation.

What all these scenarios have in common is that the most basic of bank practices - maturity transformation - raises the alarm for individuals and entities both directly and indirectly associated with banking. In its defense, maturity transformation gives deposit banks the opportunity to offer low-cost services as revenues are generated from investment activities instead of strictly relying on customer fees. Taken together, the heightened awareness of the costs of maturity transformation gives credence to the possibility that the cost-benefit analysis of the practice is in need of reassessment. One way to proceed with this reassessment is to return to Hübner's "golden rule" and uncover the relationship between bank assets and liabilities.

The original considerations as to why the golden rule was created are now long forgotten, but the relationship between the practice and the business cycle is gaining attention. Much of the literature on the topic settles on a corner solution: Either maturity transformation is an essential bank activity that must continue, lest the industry be jeopardized, or it is a complication for economic calculation, and is thus a potential instigator of the business cycle (Jankovic 2011). We challenge both these claims. Maturity transformation will only foster economic instability under certain conditions. These conditions are not strictly economic in origin. Instead, an appeal must be made to a property rights analysis to determine when the practice is legally permissible and economically beneficial. We also show that banks, which are fully responsible for and cognizant of the risks of the practice, will not instigate the business cycle.

\section{Maturity Transformation: Much Ado About When Money's Due}

Anecdotal evidence suggests that the recent recession was due to (at least, in part) excessive maturity mismatching by the banking sector (Goodhart 2008). This problem is not new, nor has its ill effects evaded attention.

Several recent cases are pertinent. Swap lines opened by the Fed and other central banks during the crisis gave banks access to short-term funding necessary to meet their short-term obligations (Obstfeld, Shambaugh and Taylor 2008). In the absence of such liquidity provisions, banks' liabilities would have come due prior to their ability to liquidate assets of sufficient quantity to stave off insolvency. In what was perhaps the most extreme case of instability, the nation of Iceland succumbed to insolvency as it tried bailing out its banking sector faced with this maturity transformation-induced liquidity constraint (Bagus and Howden 2011; Howden 2013a, 2013b). The bank runs in late 2008, exemplified by Northern Rock in the United Kingdom, were an 
example of the effects of this practice in extremis (Shin 2009). Using depositors' funds to finance longer-term projects, banks were caught in a liquidity squeeze as liabilities of zero maturity (i.e., those available on demand) were being claimed against assets of positive maturity (i.e., those requiring some time to liquidate). Banks were unable to liquidate assets quickly enough to meet redemption demands when the demand for money increased rapidly. More recently, during the Eurozone crisis, depositors have been moving savings out of unstable countries - primarily the European periphery - and depositing their funds in the perceived safety of core-European banks (Slater 2012).

That the problem is not new can be seen in the prescriptions recommended to deal with such liquidity constraints from bygones past. Henry Thornton (1802) and Walter Bagehot (1873) advocated the lender-of-last-resort facility to save banks stricken with just such misfortune. Under such schemes, however, credit would only be made available to those banks that were solvent if given enough time, and thus only suffering from a temporary lack of liquidity. While the lender-oflast-resort function rectifies the apparent problem of undercapitalized banks suffering a run on their assets, it does little to remove the incentive creating the run in the first place. To remove this incentive, D.W. Diamond and P.H. Dybvig (1983) recommend deposit insurance as the optimal response to a fractional-reserve banking system that continually faces redemption threats. By removing ex ante the threat that a deposit will not be honored in the future, deposit insurance should result in fewer - or, optimally, no - bank runs.

Unfortunately, both of these methods to deal with liquidity-constrained banks have their drawbacks. It is difficult for regulators to distinguish illiquid yet solvent banks from illiquid and insolvent ones. In the savings and loan crisis of the 1980s, over 90 percent of emergency loans from the Federal Reserve went to financial institutions that eventually failed (Kaufmann 1999). Moral hazard is the most commonly cited issue with bailouts and insurance plans (Benston and Kaufman 1996; Kaufmann 1996). Removing the threat of depositor losses also removes the incentive for depositors to monitor their bank's stability (Ely 1999). Historical evidence bears witness to insured and guaranteed banking systems succumbing to riskier lending and less prudent asset management (Thies and Gerlowski 1989).

All of these destabilizing cases are brought by the same root problem - bank assets with a longer maturity than their corresponding liabilities. The nature of banking contracts is often the central issue determining banking stability (Bhattacharya, Boot and Thakor 1998). Since banks typically contract their liabilities for a shorter maturity than their assets, redemption requests leave the potential to make binding an - albeit temporary - liquidity constraint. In none of the aforementioned cases, however, is it clear that the problem is the maturity transformation. Indeed, given appropriate constraints, maturity mismatching is sustainable and beneficial.

\section{Conditions for Sustainable Maturity Transformation}

The first question to address when assessing the practice of maturity transformation is whether the relevant parties are endowed with the rights to facilitate such activity. In particular, and following Jesús Huerta de Soto (2006) and Philipp Bagus and David Howden (2009, 2013), we approach the problem by looking at the contracts governing such transactions.

Any transfer of property from one individual to another with the expectation of the transaction being reversed in the future can broadly fit into one of two categories: a deposit or a 
loan. Each is nonspecific in that it can involve either specific or fungible goods. Each entails the physical transfer of property, and the duration of the transfer can range from the very short term to the very long term. There are three significant economic differences between the two contracts that define them (Huerta de Soto 2006, ch. 1; Bagus and Howden 2009, 2013).

First, a loan contract exchanges a present good for a claim to a future good. A lender lends money which the borrower pledges to repay in the future. In distinction, under deposit contracts there is no such intertemporal exchange of goods (Mises 1971, 269). The depositor retains at all times a claim on the deposited good, and thus makes no such exchange for a future good. As a corollary, depositories do not gain the money that is deposited in them, but must instead keep it on hand for the depositor to claim on demand.

The second difference is that loan contracts necessarily involve the transfer of the asset's availability. In a money loan, for example, the lender sacrifices the availability and use of the money for the duration stipulated by the loan. The borrower is thus at liberty to use the money as he/she wishes, only under the constraint that it be returned before the contract's duration. Deposits do not entail this same transfer of use, as the depositor has made the deposit under the pretense of keeping the asset available at all times.

Finally, while loan contracts always involve an inter-temporal exchange of goods, deposit contracts are $a$-temporal. This is significant, as a temporal contract results in a value spread due to the uncertainty of the completion of the contract's terms in the future (Shackle 1967, 203). The uncertainty inherent in the as-yet-to-be-completed contract necessitates remuneration. As a result, the lender will be remunerated for relinquishing the use and availability of his/her good for the duration of the contract, typically explicitly through an interest payment. Depositories must be remunerated for holding the depositor's assets, commonly through a fee. ${ }^{2}$

These economic differences are not without ramifications. They result in three significant legal differences, which shape the range of activities that one may undertake with these assets.

First, the contracts represent distinct legal purposes. As a loan represents the transfer of property, it also represents the borrower's gain of the use of the asset. Since a deposit is not undertaken with the intent to transfer property, the depository is prohibited from using the asset. Such practice is common in deposit contracts for other types of goods, both fungible and specific. The prohibition on using the contents of safety deposit boxes is an example in the case of specific goods. Similarly, specific laws against grain elevators making use of deposited wheat have been enforced by U.S. law since the 1860s (Williams 1984). Money deposits are treated separately under the common law since the 1848 ruling in Foley v. Hill, after which the British House of Lords "finally declared demand deposits with banks to be loans to the bankers" (Kim 2013, 812). Countries resting on a civil law tradition are ambivalent on the issue. For example, Germany de facto chooses to not enforce its laws prohibiting the use of a deposit by a bank (Köhler 2013, 916920), while in Spain such legal prohibition is only partially enforced (Bagus, Howden and Gabriel 2015; Huerta de Soto 2006, 125-129). At any rate, legal ambiguities do not negate the underlying legal necessity that depositories and depositors must have the same end in mind when forming a contract (i.e., there must be a "meeting of the minds"). ${ }^{3}$

Second, loan contracts must establish a maximum duration before it must be reversed (even if only implicitly, as in Bagus, Howden and Gabriel 2015). A good "loaned" for no time is a deposit. A good "loaned" for an unlimited period is a gift. The intermediary cases where goods are loaned for finite periods are those that concern the loan contract. Loans must have a finite maturity to 
give meaning to the claim to a future good. There is no way to do a cost-benefit analysis with regard to the attractiveness of a loan's terms lacking a maximum waiting period for the lender to access his/her claim to a future good. ${ }^{4}$

The final legal difference concerns the obligations involved. These obligations differ as per the type of contract entered into (deposit or loan), and by the type of good contracted for (specific or fungible). Specific goods under loan must be returned in their same state (or a pre-stipulated one) at the contract's termination. These contracts are known as commodatum contracts. If the good under contract is fungible, the result is a mutuum contract. In such a case, it is only important that an equivalent quantity and quality of contracted units be returned upon the contract's duration. These units become the tantundem of the loan, which must be remitted to the lender to terminate the contract.

Deposit contracts cannot entail this same legal requirement, as the good in question must remain under custody. In other words, it is not possible to repay for the use of the good when the termination of the transaction is defined as the return of the original deposited good to its owner. A distinction will still exist between specific and fungible goods. Specific goods, like a document deposited in a safety deposit box, must be returned upon request to terminate the deposit contract. Fungible goods, like money in a deposit account, may be returned in the form of an equal quantity and quality of money units, again, the tantundem. Note that the use of a deposited good during the contract's duration, even if the good can still be returned upon termination, is considered a breach of contract. If an individual places a diamond ring in a safety deposit box at a bank, the bank is culpable for breach of contract if they remove and use that ring during the contracted period, even if they return it safely to the depositor upon the termination of the contract. Safekeeping is the key role of the depository.

These three legal distinctions provide for different types of activities that may be pursued with an asset, dependent on the manner in which the asset was originally obtained. While depositories are limited in what they may legally do with the deposited assets, loans create a different story. As the only obligation that a borrower has is to return either the specific loaned good or its tantundem upon the loan's termination, no legal obligation dictates what activities the borrower can use the good for in the interim. While it is certainly risky for a lender to lend under such legal conditions, they are remunerated for the risks of such activity (in opposition to the depositor, who pays for such analogous services). Caveat commodator becomes the lender's warning.

\section{Risks and Consequences of Maturity Transformation}

The legalese of different contracts might be but a footnote of economic trivia if it was not for the repercussions on the financial system. The contractual obligations created imply that banks and other financial intermediaries are constrained in the way they can use their funding and for what.

Deposited funds cannot legally be "loaned" out or used by the depository. The reason is simple: deposited funds cannot be considered the property of the depository. Consequently, the depository (i.e., bank) is not entitled to make use of these deposits. Loans (e.g., certificates of deposit or other time deposits) are a different story. Despite claims to the contrary (Barnett and Block 2009, 2011), there is no legal argument as to why loaned funds cannot be employed by the borrower. There is also no reason why the loaned funds cannot be employed knowing that they will not be made available until a time after the loan contract's duration. The only legal stipulation 
is that the loan be repaid on or before its maturity, with no concern given to the means through which it will be repaid.

As a practical matter, it is difficult to discern which lending activities are supported by loans secured by the bank, and which are funded through its depositors. Since money is fungible, it is impossible to distinguish the funding source of any lending activity. Any individual bank can discern the nature of its lending activities, but since loaned deposits are re-deposited throughout the banking system (i.e., through the money multiplier), in the aggregate, there is no knowledge as to the origin of deposited sums (Howden 2010). In the decade prior to 2008, the M1 money multiplier averaged 1.75, implying that banks issued loans and fiduciary media in excess of their core deposits by 75 percent. With the increase in reserves following the financial crisis, the money multiplier has decreased to around 0.75, implying that banks are holding more reserves than their deposit base.

Some authors worry that loaning out funds for a maturity past that which they are due will promote economic instability (Barnett and Block 2011; Jankovic 2011). In light of the apparent liquidity constraints on banks during the latest financial crisis, this is not an unreasonable conclusion. Yet, such instability will not necessarily arise due to two reasons.

First, an issuance of fiduciary media has the potential to breed general economic instability (Hülsmann 2009). ${ }^{5}$ Fiduciary media consists of any perfect money substitute that is not backed fully by the monetary base (Huerta de Soto 2006, 187). Today, this primarily takes the form of demand deposits within the fractional-reserve banking system. A common argument equates maturity mismatching with the issuance of fiduciary media (Jankovic 2011, 121). While this is true if the collateralizing assets are redeemable on demand, the situation is much different for maturity mismatching loans of distinct durations. In the latter case, no fiduciary media is issued as the transaction is one of issuing credit against borrowed credit. With no created fiduciary media, there is no monetary trigger to set in motion the business cycle.

The second reason concerns the risk of the practice. While maturity mismatching has no legal roadblocks, it is undoubtedly a risky exercise. For fungible assets like money, the risk is usually only a relative one in that profits are affected without necessarily endangering solvency. This arises because a bank that has loaned out borrowed funds can access additional funds on the loans market to finance its obligations as they come due, even if it may not be at an advantageous borrowing rate. In this case a bank's bottom line might be compromised, but barring anything similar to a "sudden stop" (Calvo 1998), where loans of an appropriate maturity are no longer available at any price, solvency will not be threatened. Lending money in this case is not only caveat commodator, but also caveat mutuodor.

The risk of borrowing short-term and lending long-term is mitigated via two conditions. First, when the money supply is increasing, the future availability of money is increased relative to the present availability. For a bank that knowingly lends today against future borrowing, it is apparent that maturity mismatching will be promoted accordingly with the reduction in risk that future borrowing will not be available. The second condition is the provision of a lender of last resort. If an institution - such as a central bank or government treasury - exists with an explicit purpose to bail out illiquid institutions, the risk of maturity mismatching assets and liabilities decreases. This general socialization of losses, but privatization of gains from the practice, promotes its occurrence. Financial intermediaries, secure in knowing that funds will be forthcoming should they be unable to roll over their financing, will participate in an increased amount of the risky practice (Bagus and 
Howden 2010, 75-78). In most developed economies, a central bank functions (at least, implicitly) as a lender of last resort to aid illiquid banks in just such instances. ${ }^{6}$

If a central bank with lender-of-last-resort facilities promotes the practice of maturity transformation, one could ask what consequences await a banking system lacking an institution with this role. In such cases, the interest rate serves an additional purpose in moderating the practice. Originary interest rates are well-known to coordinate inter-temporal activities, as well as equilibrate planned saving with investment. The originary interest rate is the product of the uncertainty inherent between the present and some future date. To the extent that the borrower's future availability to repay a loan is uncertain, a premium is established in the present.

Of the factors that are added to the originary rate to achieve the market rate of interest, we are primarily concerned with the risk premium. Lenders, aware of the practice of maturity transformation, demand a risk premium from borrowers in addition to what they would charge for a less risky, maturity-matched use of the funds. This effect serves as an interest rate brake on the practice, especially pronounced in an environment lacking a continual increase in credit availability, or a lender of last resort. The effect of this brake intensifies with strengthening the degree of maturity transformation undertaken at any point in time. If more funds are loaned out than the bank has maturing in any period, it will have to borrow additional funds to make up the difference. This implies that the future demand to borrow funds will increase as present lending increases. Ceteris paribus, this places upward pressure on future interest rates, and forward-looking lenders discount these higher future rates back to the present. ${ }^{7}$ The net effect is that borrowers will need to pay higher rates in the present to finance their lending, and this effect is more pronounced as the disparity between present borrowing and present lending deepens.

In this way the interest rate takes on a twofold "braking" role. Interest rates serve to limit overinvestment by increasing in response to an increased demand for borrowed funds. As a result, an exogenous shock to the economy - in the form of a technological advancement, for example cannot result in an over- or mal-investment-type boom-bust cycle. Interest rates will increase in response to an increased demand for borrowing funds, thus slowing the rate of adoption and keeping the structure of production from unduly deepening (Garrison 2001, 60). Note that this does not negatively affect the development of technological advancement. This advancement was the original force that caused interest rates to increase, and this increase in the rate will not inhibit its appearance. Friedrich A. Hayek $(1933,94,179)$ referred to this phenomenon as the "interest rate brake" that would allow investment to proceed while signaling to entrepreneurs when the economy was beginning to overheat. The interest rate serves as the intertemporal coordinator of production plans, assuring that the duration of production processes is aligned with the supply of real savings. In addition, we can now see that the interest rate serves as a coordinator of borrowing, ensuring that the present supply of loanable funds is balanced against its expected future supply. However, this does not mean that the present and future funds' supplies must be equal, but only that the interest rate will coordinate the redemptions and availabilities of such funds in a sustainable manner (Garrison 2004).

The interest rate brake works to motivate financial intermediaries to transform maturities up to a finite and sustainable amount. The interest rate then serves to maintain two equilibria. On one hand, the rate coordinates inter-temporal transactions. On the other hand, the rate serves to ensure that financial intermediaries use the funds that they have in their possession, and are legally permitted to use (i.e., loans), in a responsible and sustainable manner. 


\section{Conclusion}

Hübner was not altogether incorrect when he reckoned that bank's liabilities should not fall due prior to their funding. However, his "golden rule" of banking was limited to a special case.

Financial intermediaries are only legally permitted to use funds transferred to them. In modern banking contracts, such transfers are typically in the form of short-term loans or timedeposit accounts. With these funds, the bank is allowed to issue credit in excess of the funding available, as well as for a longer duration than the funding is projected to be available for. That this practice is risky is largely outside the scope of economic analysis. More important are three notes about this practice:

1. Continual increases in the credit supply reduce the risk inherent in the practice of maturity transformation and thus promote it beyond what would otherwise be obtained.

2. The feature of a lender of last resort in the economy allows financial intermediaries to socialize some of the risk inherent in the practice, while securing the resultant profits. The lender of last resort thus promotes the practice of maturity transformation.

3. An interest rate brake then serves to equilibrate the demand for present borrowing with the expected future supply of lending necessary to sustain it. For this brake to function effectively, both the continual increase in the credit supply and the lender-of-last-resort function must be removed completely from the economy.

We should note that Hübner was correct in one regard. The golden rule of banking is applicable to the deposit obligations of a bank. A bank is not at liberty to use funds that have not been loaned to it, along with the accompanying transfer of use rights. Today, these obligations exist mostly in the form of demand deposits. As deposits lack maturity, they must be available continually on demand. This necessarily implies that banks are not entitled to lend out such funds in a practice that can be characterized as maturity transformation in extremis.

Lamentably, today's financial world does not abide by the laws we describe here. Banks are permitted to legally lend against their demand deposits, albeit constrained by a reserve ratio in some jurisdictions. The lender of last resort exists in almost every developed economy. Continual increases in the credit supply have rendered the practice relatively riskless, and promoted its use to the levels that we currently see. In this regard, economists like Barnett and Block $(2009,2011)$ and Jankovic (2011) are partially correct to decry the practice. But the part that they should decry is not the practice of maturity transformation as such, provided that it functions within a set of guidelines. Most importantly, as long as a bank loans only against money that has been loaned to it, there is no legal issue.

We endeavor to create a clear imperative in placing the responsibility of economic instability on the proper culprits. Socialized financial losses via a lender of last resort have removed the threat of illiquidity and eventual insolvency for many financial institutions. The continual expansion of credit has removed the risk that future funds will not be available to borrow when the time arises to finance the borrowing done in the present. Rectifying these two issues will largely mitigate any instability caused by the financial practice of maturity transformation. 


\section{Footnotes}

${ }^{1}$ Other factors are relevant besides the ability of banks to honor redemption requests on demand. In Greece's recent history, the outflow of money is partly caused by this reason, although it is also a reaction against expected capital controls prohibiting depositors from moving their money to safer banking systems in the future, as was the case in Cyprus in 2013.

${ }^{2}$ If a fee is not explicitly stated, the depository is including the service at a loss which it will, optimistically, recoup through other business activities (Bagus and Howden 2009, 400 fn5).

${ }^{3}$ While the specific legal obligations heaped on depositories are a question for the legal system, the existing framework of the law does not necessarily have to be correct or optimal (Bagus, Howden and Block 2013), whether through faulty logic in constructing laws in civil law jurisdictions, or as a result of poor case precedents in areas subject to common law.

${ }^{4}$ That in practice there is a continuum of availabilities is of no immediate concern to us here. Philipp Bagus and David Howden (2012b) address this issue, arguing that even if availabilities are only vaguely defined, the legal system is the appropriate institution to determine whether money has been deposited or loaned.

${ }^{5}$ Typically, economic disruptions put in motion by issuances of fiduciary media fall under the category of Austrian Business Cycles (Garrison 2001; Hayek 1935; Mises 1971; Rothbard 1962). Either the schema of relative prices is upset (Mises 1928, 100-103), or entrepreneurial knowledge of the origin or sustainability of the new money is lost as fiduciary media is issued (Howden 2010). In either case, inter-temporal consumption and investment plans are upset, thus breeding instability in the real economy. Alternatively, one could view the rise in interest rates on the eve of the business cycle's bust phase as a response to the expectations of falling income and a withdrawal of loanable funds from the market.

${ }^{6}$ By promoting this destabilizing practice, the central bank creates a net negative welfare effect on the economy. In addition, it also causes a situation that necessitates its facilities to create fiduciary media. By engendering economic instability, central banks create the appearance that it is necessary to provide credit to keep the system liquid (Bagus and Howden 2012a, sec. 3).

${ }^{7}$ Included among these cetera is a lack of a lender of last resort. One result of this function is a diminished importance placed on the interest rate as a brake on present maturity transformation.

\section{References}

Bagehot, Walter. Lombard Street: A Description of the Money Market. London: Henry S. King and Co., 1873.

Bagus, Philipp and David Howden. "The Legitimacy of Loan Maturity Mismatching: A Risky, But Not Fraudulent, Undertaking." Journal of Business Ethics 90, 3 (2009): 399-406.

—. "The Term Structure of Savings, the Yield Curve and Maturity Mismatching." Quarterly Journal of Austrian Economics 13, 3 (2010): 64-85.

—. Deep Freeze: Iceland's Economic Collapse. Auburn, AL: Ludwig von Mises Institute, 2011.

—. "Some Ethical Dilemmas with Modern Banking." Business Ethics: A European Review 22, 3 (2012a): 235-245.

—. "Still Unanswered Quibbles with Fractional Reserve Free Banking." Review of Austrian Economics 25, 2 (2012b): 159-171. 
- "The Continuing Continuum Problem of Deposits and Loans." Journal of Business Ethics 106, 3 (2012c): 295-300.

Bagus, Philipp, David Howden and Walter E. Block. "Deposits, Loans and Banking: Clarifying the Debate.” American Journal of Economics and Sociology 72, 3 (2013): 627-644.

Bagus, Philipp, David Howden and Amadeus Gabriel. "Oil and Water Do Not Mix, or: Aliud est Credere, Aliud Deponere.” Journal of Business Ethics 128, 1 (2015): 197-206.

Barnett, William and Walter E. Block. "Time Deposits, Dimensions and Fraud.” Journal of Business Ethics 88, 4 (2009): 711-716.

—. "Rejoinder to Bagus and Howden on Borrowing Short and Lending Long." Journal of Business Ethics 100, 2 (2011): 229-238.

Benston, George J. and George G. Kaufman. "The Appropriate Role of Bank Regulation.” Economic Journal 106, 436 (1996): 688-697.

Bhattacharya, Sudipto, Arnoud W.A. Boot and Anjan V. Thakor. The Economics of Bank Regulation. Journal of Money, Credit, and Banking 30, 4 (1998): 745-770.

Brunnermeier, Markus K. "Deciphering the Liquidity and Credit Crunch 2007-2008." Journal of Economic Perspectives 23, 1 (2009): 77-100.

Calvo, Guillermo A. "Capital Flows and Capital-Market Crises: The Simple Economics of Sudden Stops." Journal of Applied Economics 1, 1 (1998): 35-54.

Diamond, Douglas W. and Philip H. Dybvig. "Bank Runs, Deposit Insurance, and Liquidity." Journal of Political Economy 91, 3 (1983): 401-419.

Ely, Bert. "Regulatory Moral Hazard: The Real Moral Hazard in Federal Deposit Insurance." Independent Review 4, 2 (1999): 241-254.

Farhi, Emmanuel, and Jean Tirole. "Collective Moral Hazard, Maturity Mismatch and Systemic Bailouts." American Economic Review 102, 1 (2012): 60-93.

Freixas, Xavier and Jean-Charles Rochet. Microeconomics of Banking. Second edition. Cambridge, MA: MIT Press, 2008.

Garrison, Roger W. Time and Money: The Macroeconomics of Capital Structure. London: Routledge, 2001.

Garrison, Roger W. "From Keynes to Hayek: The Marvel of Thriving Macroeconomics." Review of Austrian Economics 19, 1 (2004): 5-15.

Goodhart, Charles A.E. "The Background to the 2007 Financial Crisis." International Economics and Economic Policy 4, 4 (2008): 331-346.

Hayek, Friedrich A. Monetary Theory of the Trade Cycle. Translated by Nicholas Kaldor and H.M. Croome. New York, NY: Sentry Press, 1933.

—. Prices and Production. Second edition. London: Routledge, 1935.

Howden, David. "Knowledge Shifts and the Business Cycle: When Boom Turns to Bust." Review of Austrian Economics 23, 2 (2010): 165-182.

- "Separating the Wheat from the Chaff: Icelandic and Irish Policy Responses to the Banking Crisis.” Economic Affairs 33, 3 (2013a): 348-360.

—. "The Rise and Fall of the Icelandic Economy." Journal for Social, Political, and Economic Studies 38, 4 (2013b): 389-424.

Hübner, Otto. Die Banken. Leipzig, Germany: Verlag von Heinrich Hübner, 1854. 
Huerta de Soto, Jesús. Money, Credit and Economic Cycles. Translated by Melinda Stroup. Auburn, AL: Ludwig von Mises Institute, 2006.

Hülsmann, Jörg Guido. "The Demand for Money and the Time-Structure of Production.” In Property, Freedom, $\mathcal{E}$ Society: Essays in Honor of Hans-Hermann Hoppe, edited by Jörg Guido Hülsmann and Stephan Kinsella, pp. 309-324. Auburn, AL: Ludwig von Mises Institute, 2009.

Jankovic, Ivan. "Economic Calculation, Maturity Mismatching and the Credit Cycle." New Perspectives on Political Economy 7, 1 (2011): 105-124.

Kaufman, George G. "Bank Failures, Systemic Risk, and Bank Regulation.” Cato Journal 16(1) (1996):

http:// citeseerx.ist.psu.edu/viewdoc/download?doi=10.1.1.518.9096\& rep=rep1\& type=pdf.

—. "Do Lender of Last Resort Operations Require Bank Regulation?" Paper presented at the conference "Is Bank Regulation Necessary?" of the American Enterprise Institution, Washington D.C., October 27, 1999.

Kim, Jongchul. "Modern Politics as a Trust Scheme and Its Relevance to Modern Banking." Journal of Economic Issues 47, 4 (2013): 807-826.

Köhler, Michael von. "Hume's Dilemma - Oder: Was ist Geld? Geldschöpfung der Banken als Vermögensrechtsverletzung." In Grundlagen und Dogmatik des gesamten Strafrechtssystems, Festschrift für Wolfgang Frisch zum 70. Geburtstag, edited by G. Freund, U. Murmann, R. Bloy and W. Perron, pp. 878-923. Berlin, Germany: Duncker \& Humblot, 2013.

Obstfeld, Maurice, Jay C. Shambaugh and Alan M. Taylor. "Financial Instability, Reserves, and Central Bank Swap Lines in the Panic of 2008.” NBER working paper no. 14826. NBER, 2009.

Rothbard, Murray N. America's Great Depression. Fifth edition. Auburn, AL: Ludwig von Mises Institute, [1962] 2000.

Slater, Steve. "Greeks Not Alone in Bank Savings Exodus." Reuters, May 17, 2012.

Shin, Hyun Song. "Reflections on Northern Rock: The Bank Run that Heralded the Global Financial Crisis." Journal of Economic Perspectives 23, 1 (2009): 101-119.

Thies, Clifford F. and Daniel A. Gerlowski. "Deposit Insurance: A History of Failure.” Cato Journal 8, 3 (1989): 677-693.

Thornton, Henry. An Enquiry into the Nature and Effects of the Paper Credit of Great Britain. London: George Allen and Unwin, 1802.

Von Mises, Ludwig. The Theory of Money and Credit. Translated by H.E. Batson. Irvington-onHudson, NY: Foundation for Economic Education, 1971.

- "Monetary Stabilization and Cyclical Policy." In On the Manipulation of Money And Credit, translated and edited by B.B. Greaves, Jr., and P.L. Greaves, Jr., pp. 63-179. Auburn, AL: Ludwig von Mises Institute, [1928] 2002.

Williams, Jeffrey C. "Fractional Reserve Banking in Grain.” Journal of Money Credit and Banking 16, 4 (1984): 488-496 